\title{
PRO HOMINE PRINCIPLE: AN AXIOLOGICAL COMPASS IN INTERPRETATION NORMS IN THE FIELD OF HUMAN RIGHTS
}

\author{
SAMANTA KOWALSKA ${ }^{1}$
}

\begin{abstract}
The pro homine principle plays an important role in the objectification of the legislative process and the interpretation of regulations. The current paper presents the pro homine principle as a means of realisation and a "canon of interpretation" in the pursuit of more effective and more efficient protection of the rights of the individual. The discussed principle may also be used to fill in lacunas in international treaties, as well as to ensure axiological cohesion, which may lead to crystallisation, clarification of norms or their evolution into principles of conventional nature. Implementation of the pro homine principle supports in detecting and counteracting arbitrariness and identifying protective measures that remain merely declarative in nature.
\end{abstract}

Keywords: pro homine principle, human rights, international agreement, interpretation and application of treaty norms, axiology of human rights

Summary: 1. Introduction. 2. The essence of the pro homine principle. 3. Internationalisation of PROTECTION AND NORMALISATION OF THE PRO HOMINE PRINCIPLE. 4. INTERPRETATION NORMS IN THE CONTEXT OF CUSTOMARY LAW AND TREATY LAW. 5. THE PRO HOMINE PRINCIPLE IN A GLOBALIZED WORLD. 6. ROLE THE PRINCIPLE Pro homine in dialogue of Legal sources. 7. Prism of the pro homine Principle. 8. Conclusions

\section{INTRODUCTION}

In the light of international human rights law, the pro homine principle is a fundamental instrument for the protection of individual rights. The aim of the pro homine principle is to make human rights a reality to the fullest extent possible. In the term "human rights" despite differences in terminology, a common axiom can be isolated ${ }^{2}$. Even as far back as ancient Indian times, it was believed that the right of one person is the obligation of the other ${ }^{3}$. This has found its reflection in the modern concept of human rights, which is not unilateral, but balanced in its rights and obligations. Pro

\footnotetext{
${ }^{1}$ PhD, lawyer. The President Stanisław Wojciechowski University in Kalisz, Poland (skowalska13@ interia.pl).

${ }^{2}$ In the literature of the subject, one may find the statement that "the idea of international human rights, like other human ideas, is a remix". In: Martinez, J.S. 2013. Human Rights and History. Harvard Law Review, Volume 126, Number 7, p. 237. Human rights develop in a particular social, cultural and ideological environment. The current reflections emphasise the "meta depth" of regulations concerning the rights and liberties of an individual, which can serve both the domestic legislator and the international community by acting as a common ground which doesn't cause corrosion of the principle of respect of national sovereignty. ${ }^{3}$ Madan, N. 2017. History \& Development of Human Rights in Indian, IOSR Journal of Humanities and Social Science, Volume 22, Issue 6, Ver. 9, p. 1. Cf. OESTREICH, J.E. 2017. Development and Human Rights: Rhetoric and Reality in India, Oxford: Oxford University Press.
} 
homine principle can help a distillation of norms and prevent against blurring of the genesis of human rights. Individual rights are derived from the inborn and inalienable of human dignity. Recognition of human rights is the sine qua non condition of respect for dignity. In light of the above, the key role of the principle is to protect human dignity and the rights that emanate it. The discussed principle emerges as a means of protecting human rights that are enjoyed by every individual for the mere fact of being human. Due to this fact, the pro homine principle can be regarded as a symbolic mirror that allows us to capture the symptoms of treating people in a manner that is contrary to the model resulting from dignity.

\section{THE ESSENCE OF THE PRO HOMINE PRINCIPLE}

According to the American Declaration of the Rights and Duties of $\mathrm{Man}^{4}$, one is not eligible to human rights for being a citizen of a specific country, but due to attributes resulting from human personhood. This issue was emphasized by Seyla Benhabib, who indicated that legal protection is granted by virtue of being a human being, a moral being 5 . The evocation of morality directs attention to axiology, which should permeate both substantive and procedural provisions. This corresponds to Rodolfo E. Piza Escalante's argument that the pro homine principle follows from human nature itself ${ }^{6}$. Since human rights are inherent in human nature, the pro homine principle can help bring them out their ,real life-value foundation" ". The principle is ontologically, legally and axiologically intertwined with human life. In the light of this principle, the human being is the subject, and the highest goal ${ }^{8}$. Hence, the pro homine principle leads to the most favourable interpretation for the individual ${ }^{9}$.

In this respect, the interpreting party plays a significant role. The interpretation process consists of activities aimed at determining the meaning of the words used in the legal text ${ }^{10}$. When establishing or reconstructing the meaning of expressions, one must observe the individual 'colours' and 'shades' of human life. This is often associated with the need to have not only specialist legal knowledge, but also sensitivity combined with subtle tact, e.g. when interpreting norms concerning the right to life, confessional views or the protection of privacy.

\footnotetext{
${ }^{4}$ American Declaration of the Rights and Duties of Man Adopted by the Ninth International Conference of American States, Bogotá, Colombia, 2 May 1948.

${ }^{5}$ Benhabib, S. 2009. Cosmopolitanism and Democracy: Affinities and Tensions, The Hedgehog Review. Critical Reflections on Contemporary Culture, Volume 11, Issue 3, p. 31.

${ }^{6}$ Opinion Separate of Judge R.E. Piza Escalante is quoted for: Medellín Urquiaga, X. 2013. Principio pro persona, Axotla: Suprema Corte de Justicia de la Nación, Oficina en México del Alto Comisionado de las Naciones Unidas para los Derechos Humanos y Comisión de Derechos Humanos del Distrito Federal, p. 17. ${ }^{7}$ Noonan, J. 2018. Human Rights as Hinge Principles, International Critical Thought, Volume 8, Issue 3, p. 12.

${ }^{8}$ Berbera, H.R. 2018. The Pro Personae Principle and its Application by Mexican Courts, Queen Mary Human Rights Law Review, Volume 4, p. 6.

${ }^{9}$ Amaya Villarreal, Á.F. 2005. El principio pro homine: interpretación extensiva vs. el consentimiento del Estado, International Law. Revista Colombiana de Derecho Internacional, Volume 3, Número 5, p. 351. ${ }^{10}$ Tobin, J. 2010. Seeking to Persuade: A Constructive to Human Rights Treaty Interpretation, Harvard Human Rights Journal, Volume 23, p. 5.
} 
In the light of the pro homine principle, if an extensive interpretation would lead to an arbitrary or restrictive limitation of the rights of an individual, it is advisable to refrain from the aforementioned explication. Applying the principle for interpretation may therefore mean adopting a narrower interpretation in justified cases, if it would provide an individual with better protection. Interpretation of standards should be correlated with the mechanisms ensuring their effective implementation. An interpretation with the use of this principle should lead to "the immediate and unconditional enforceability of human rights" ${ }^{11}$. For Rodolfo E. Piza Escalante, this should be the rule, not the exception ${ }^{12}$. However, it is advisable to consider each case in the light of the circumstances of the case. The pro homine principle is not based on the use of models, but on the individualisation of measures. Interpretation using the pro homine principle is intended to assist the process of examining standards taking into account the circumstances and the context of the treaty. It facilitates the identification of phenomena that could unravel the integrity of the legal system. In terms of practice, the analysed principle makes it possible to formulate conclusions concerning not only internal but also international provisions in terms of the purpose of the law (ratio iuris) and legal norms (ratio legis). Adopting the above understanding opens the way to greater effectiveness of the protection of an individual (protective goals) and of the values approved by them (goals, effects) ${ }^{13}$. Referring to the pro homine principle opens new possibilities in the protection of human rights that have not been included in treaties in a comprehensive manner or to a satisfactory extent.

\section{INTERNATIONALISATION OF PROTECTION AND NORMALISATION OF THE PRO HOMINE PRINCIPLE}

Achieving universalism and its concretisation in the form of regional systems of human rights protection can certainly be considered a milestone in human history ${ }^{14}$. The proclaim of the Charter of the United Nations ${ }^{15}$ opened a new chapter in international relations and changed the hitherto understanding of international law. Internationalisation of human rights brought about an introduction of abstract and general norms whose purpose was the protection of the individual in the personal and the social aspect. In the preceding period of time, determination of the legal status of an individual was believed to fall within the authority of a state. For the first time, the UN Charter laid the foundation for the crystallisation of standards aimed at protecting individuals in the context of international law. Among the obligations of the state, respect for human rights and ensuring conditions in which they could be respected and stably secured were indicated. Private persons were given the ability to submit individual applications to an international

\footnotetext{
${ }^{11}$ Opinion Separate of Judge R.E. Piza Escalante, Supra note 6, 17.

12 Supra note 11.

${ }^{13}$ Kowalska, S. 2019. Zasada pro homine - konceptualizacja i zastosowanie w kontekście międzynarodowej ochrony praw człowieka / Pro Homine Principle - Conceptualization and Application in the Context of International Protection of Human Rights. Poznań: Uniwersytet im. Adama Mickiewicza w Poznaniu, Zakład Graficzny UAM, p. 38.

${ }^{14}$ Ishay, M.R. 2004. What are Human Rights? Six Historical Controversies, Journal of Human Rights, Volume 3, Number 3, p. 359.

${ }^{15}$ Charter of the United Nations was signed on 26 June 1945 in San Francisco.
} 
(organ) court. In the context of protection of human rights by the treaty, the pro homine principle enables the individualisation of norms resulting from the fact of an individual's legal and international subjectivity. The International Court of Justice judgment in the Barcelona Traction case emphasised that respect for human rights by signatory states has the nature of erga omnes obligations, which are also of vital importance for the entire international community ${ }^{16}$.

Since the adoption of the Universal Declaration of Human Rights 17 "are no longer the Rights of Man, but rather Human Rights"18. The Declaration is likened to "shining city on the hill", upon which nations and states look ${ }^{19}$. However, it should not take the form of rivalry, but cooperation for the purpose of more effective and efficient protection that recognises historical, geopolitical and cultural factors. This document constitutes an inexhaustible source of knowledge about man and about regulations adopted with a view to protection of the human being. It serves as an impulse which stimulates transformation of non-legal values into principles of normative rank.

The pro homine principle can be assigned the role of an axiological guideline supporting the identification, articulation and reconstruction of values necessary for the effective protection of an individual. Since the adoption of the Declaration, the status of the pro homine principle began to change. No longer a soft law provision, it has become a norm of general international law. The normativisation of the pro homine principle on the international forum took place with the adoption of the International Covenant on Civil and Political Rights ${ }^{20}$ and the International Covenant on Economic, Social and Cultural Rights ${ }^{21}$. Since then, the pro homine principle has been a normative guideline for making treaty norms in the field of human rights more effective. The pro homine principle apparently has the characteristics of a meta-principle through the articulation of rights and freedoms that are normatively included in international treaties.

Another meta-principle concerns the content of the provisions. The pro homine principle aims to display those values which constitute the axiological foundation of the international legal order. This takes on special significance in the light of the dynamic development in the field of science and technology, e.g. related to progress in the field of cyberspace, climate protection, counteracting pathological phenomena (terrorism,

\footnotetext{
${ }^{16}$ International Court of Justice, Reports of Judgments, Advisory Opinions and Orders, Case concerning the Barcelona Traction, Light and Power Company, Limited (Belgium v. Spain), Judgment of 5 February $1970, \S 33,34$.

${ }^{17}$ Universal Declaration of Human Rights was proclaimed by the United Nations General Assembly in Paris on 10 December 1948.

${ }^{18}$ Fletcher, W.A. 2010. International Human Rights and the Role of the United States, Northwestern University Law Review, Volume 104, Number 1, p. 297.

${ }^{19}$ Supra note 18.

${ }^{20}$ International Covenant on Civil and Political Rights adopted and opened for signature, ratification and accession by General Assembly Resolution 2200A (XXI) of 16 December 1966, entry into force 23 March 1976, in accordance with Article 49.

${ }^{21}$ International Covenant on Economic, Social and Cultural Rights adopted and opened for signature, ratification and accession by General Assembly Resolution 2200A (XXI) of 16 December 1966, entry into force 3 January 1976, in accordance with Article 27.
} 
hybrid warfare, etc.). Therefore, the pro homine principle can play an important role in rationally setting the boundaries of scientific exploration in order to protect against excessive bioengineering interference in the human genetic profile. The axiology of human rights point to the significance of the protection of psycho-physical and genetic integrity of a human. In the process of interpretation of treaty provisions, one should appeal to the 'arch-norm' that does not come from any legislator or judge. Hence the conclusion that the pro homine principle emphasises values of special importance that result from human identity.

\section{INTERPRETATION NORMS IN THE CONTEXT OF CUSTOMARY LAW AND TREATY LAW}

The earliest attempts to define customary law in relation with fundamental human rights can be found in the advisory opinion of the International Court of Justice of $1951^{22}$. The literature of the subject demonstrates that treaties tend to achieve a universal status decades after their ratification by a given signatory state ${ }^{23}$. In relation to treaties in the sphere of protection of human rights, it ought to be noted that by means of evocation of innate dignity, they are in themselves characterised by universality, since they appeal to common, extra-legal values. Integration of the pro homine principle with custom may help reach a decision in a shorter time frame, since creation of norms of customary law does not entail the necessity of lengthy, formalized negotiations. Principio pro homine may be used as subsidiary to other principles, reinforcing their message and practice and, consequently, positively influence observance of obligations of international law regarding the protection of human rights.

The general interpretative rule of international conventions is found within the Vienna Convention on the Law of Treaties ${ }^{24}$. Article 31(3)(c) prescribes that, in the process of interpretation of a treaty, "there shall be taken into account [...] any relevant rules of international law applicable in the relations between the parties". Regarding treaties from the field of human rights protection, analysis of the context ought to consider the processes that have occurred in the past and, with regards to the present, direct attention towards the genesis, the goals and the outcomes that the regulations being introduced will have on the status of the individual. In circumstances marked by insufficient procedural principles in treaties or in customary law, the pro homine principle may also be adopted to complement or 'rehabilitate' the norms of a treaty. Filling in these gaps may help reduce the number of cases of non-liquet, where the court is unable to make a determination due to a lack of an applicable legal norm. Application of the pro homine principle in court cases deepens and tightens the link between human rights and other sources of international law, substantive and procedural alike. As a result, it may prove to be an impulse for reiteration

\footnotetext{
${ }^{22}$ International Court of Justice, Reservations to the Convention on the Prevention and Punishment of the Crime of Genocide. Advisory Opinion of 28 May 1951.

${ }^{23}$ Helfer, L.R., Wuerth, I.B. 2016. Customary International Law: An Instrument Choice Perspective, Michigan Journal of International Law, Volume 37, p. 569.

${ }^{24}$ Vienna Convention on the Law of Treaties was adopted on 22 May 1969 and opened for signature on 23 May 1969.
} 
of customary law within treaty regulations with a goal of reinforcement and actualisation of the protection of the rights of an individual. Principio pro homine may also positively impact normativisation of the provisions of soft law documents, so as to improve the legal and actual status of the individual.

The pro homine principle, in conjunction with a custom that the subjects of international law believe to be in agreement with the law (opinio iuris sive necessitatis ${ }^{25}$ ) may enable a more prompt reaction in the face of a violation of human rights and, as a result, enhance the mechanisms of protection and assist in instating laws that are suited to the unfolding circumstances ${ }^{26}$. As Emily Kadens and Ernest A. Young demonstrate, lacunas are frequently found in the very areas that require legal regulation the most ${ }^{27}$. This may take the form of a legal norm that is not properly defined, a contradiction or a lack of a procedure that would outline the way a decision should be made or the action that should be taken. The lack of a legal norm that would find application in factually occurring circumstances is beyond a doubt a detrimental situation for the individual. Legal gaps may also emerge as a result of transformations in the international community, technological progress, as a consequence of engaging in new areas of research that have not been previously explored by scientists, e.g. biological engineering, space law. In this context, the regulatory role of the pro homine principle in profiling the activities of public bodies and institutions, especially those that make decisions affecting the status of an individual, becomes apparent. In the above circumstances, the pro homine principle may act as a "shield" against arbitrary interference with the status and rights of an individual.

\section{THE PRO HOMINE PRINCIPLE IN A GLOBALIZED WORLD}

The role of principio pro homine is increasing in significance due to progressing moral and cultural relativism, since adoption of relative, temporary axioms results in illusory social and legal security. Reliance on the pro homine principle may help strengthen interpersonal bonds and neutralise the negative effects of globalisation in the horizontal and vertical sphere. In many places around the globe societies are torn apart by intentionally maintained conflicts, fragmented by divisions, consumed by envy, homophobia and intolerance. The connections and interdependencies between financialeconomic systems make it so that the crisis of one centre impacts the remaining ones. We are witnessing an intensive acceleration of the phenomenon of globalisation in economy which modifies and transforms previous models of behaviour, imposing its own patterns, introjecting judgements and interpretations. The phenomenon of globalisation, despite its benefits (e.g. facilitating communication, transmitting and receiving information) also poses many threats, e.g. for national cultures and traditional values. This phenomenon

\footnotetext{
${ }^{25}$ Wolfke, K. 1964. Custom in Present International Law. Wrocław: Prace Wrocławskiego Towarzystwa Naukowego, p. 52.

${ }^{26}$ See: Helfer, L.R., Wuerth, I.B. 2016. Customary International Law: An Instrument Choice Perspective, Michigan Journal of International Law, Volume 37, pp. 575-576.

${ }^{27}$ Kadens, E., Young, E.A. 2013. How Customary is Customary International Law?, William \& Mary Law Review, Volume 54, Issue 3, p. 886.
} 
unifies patterns and norms of conduct. This process also manifests itself in striving to establish a cosmopolitan and global law that may blur the national cultural heritage and parliamentary traditions of individual countries. In the above circumstances, international institutionalisation and the language of legal texts are vernacularising ${ }^{28}$. At the time when the first treaties on the protection of the rights of the individual were drawn up, the pro homine principle made it possible to present the legal and international subjectivity of the individual. Currently, in the face of the increase in processes aimed at taking away or limiting the subjectivity of an individual and state sovereignty, there is an urgent need to be guided to a greater extent by the good of the individual, both as a single entity and as a group (protection of the national legal tradition, culture and statehood). The application of the pro homine principle may help to neutralise the negative effects of the phenomenon of globalisation, which causes instrumentalisation of law and the domination of objective and economic factors.

\section{ROLE THE PRINCIPLE PRO HOMINE IN DIALOGUE OF LEGAL SOURCES}

International human rights treaties affect domestic administrative, legislative and judicial activities. The analyzed principle may support the transposition of values resulting from international human rights law into the legislation of individual countries, but not for the purpose of unification, but for selecting solutions that will create a common ground for agreement. For example, the Constitution of Japan ${ }^{29}$ describes human rights as eternal and inviolate (Article 11). The Japanese state places great importance on honouring international legal obligations "balancing them with its cultural, historical and constitutional backgrounds" ${ }^{\prime 30}$. It is believed that treaties in the area of international protection of human rights support the process of reinforcing and broadening of the individual protection that stems from the domestic law and Japanese constitutional norms ${ }^{31}$. The pro homine principle, by means of "the dialogue of sources", 'navigates' towards the norm that, in the light of particular circumstances, ensures the most effective protection. This leads to the conclusion that the clarifying role of the pro homine principle plays an important role in lawmaking and implementation of regulations pro foro interno when it comes to prevention of internal contradictions. Furthermore, pro foro externo, the function of the discussed principle can be employed in the context of ratification of international treaties, which entail justified expectations on the part of the signatory states. Analysed the Basic Law has persisted through decades, becoming the foundation for development of the post-war political system of Japan. The Preamble speaks of a "universal principle of mankind", which suggests a connection with the pro homine principle. Hence, there is a conclusion that in the process of legislation, analysing norms through the lens of the pro homine principle may promote rational lawmaking rooted in the legal and cultural tradition of a given country, all the while respecting international legal

\footnotetext{
${ }^{28}$ See: Benhabib, S. 2009. Claiming Rights across Borders: International Human Rights and Democratic Sovereignty, American Political Science Review, Volume 103, Number 4, p. 692.

${ }^{29}$ Constitution of Japan promulgated on November 3, 1946. Came into effect on May 3, 1947.

${ }^{30}$ De Oliveira Mazzuoli, V., Ribeiro, D. 2015. The Japanese Legal System and the Pro Homine Principle in Human Rights Treaties, Anuario Mexicano de Derecho Internacional, Volume 15, Issue 1, p. 268.

${ }^{31}$ Supra note 30, p. 269.
} 
obligations. Regard for constitutional values of signatory states is especially important in the evaluation of the necessity and the proportionality of interference into the sphere of the rights and liberties of individuals. Cultural diversity, pluralism and democratic values call for a "spirit of compromise. Principio pro homine can therefore be referred to as the principle of normative conflict resolution.

The interpretation methodology based on the pro homine principle is used by the Inter-American Court of Human Rights. There is a clear influence of the pro homine principle in advisory opinion OC-5/85 32 . Taking this principle as a guideline, the interpretation of the Tribunal went beyond the treaty provisions that make up the inter-American system of human rights protection. This action was dictated by the reconstruction of the standard ensuring a balanced and most beneficial protection for the individual. In Latin American countries, the pro homine principle makes it possible to incorporate norms resulting from the American Convention on Human Rights ${ }^{33}$, which may contribute to the integration of the domestic legal order with the standards of human rights protection. In a concurring opinion, Judge Antônio Augusto Cançado Trindade pointed to the unity and universality of human rights ${ }^{34}$. The pro homine principle can support the correlation of content, interpretation and practice in the spirit of the essence of human rights, which is a common value, but also an obligation.

However, dilemmas may arise in the context of the application of the pro homine principle. Article 133 of the Mexican Constitution ${ }^{35}$ grants supremacy to the Constitution. A dilemma arose for domestic judges as regards the application and interpretation of the norms resulting from the Constitution in relation to the norms of the Treaties. The Suprema Corte de Justicia de la Nación (SCJN) took the position that the pro homine principle abolished the hierarchical organisation of human rights provisions ${ }^{36}$. In 2011, SCJN in the context of the implementation of the Rosendo Radilla Pacheco judgment ${ }^{37}$, indicated that all organs of state authority, including the judiciary, are obliged to take into account the pro homine principle in considering constitutional norms and treaty norms of international law in this matter. In 2012 SCJN developed its previous position stating that in the case of the presence of a constitutional norm and a treaty norm, it is justified to apply the provision that will provide better protection for an individual ${ }^{38}$. The Constitutional Chamber of the

\footnotetext{
$32 \S 52$, Inter-American Court of Human Rights, Advisory Opinion OC-5/85 of November 13, 1985, Compulsory Membership in an Association perscribed by Law for the Practice of Journalism (Arts. 13 and 29 American Convention of Human Rights). Requested by the Goverment of Costa Rica.

${ }^{33}$ American Convention on Human Rights signed in San José, Costa Rica on 22 November 1969.

${ }^{34} \S 5$, Concurring Opinion of Judge A.A. Cançado Trindade. In connection with the Inter-American Court of Human Rights, Advisory Opinion OC-18/03 of September 17, 2003. Requested by the United Mexican States, Juridical Condition and Rights of Undocumented Migrants.

${ }^{35}$ Constitution of Mexico was approved on February 5, 1917.

${ }^{36}$ Berbera, H.R. 2018. The Pro Personae Principle and its Application by Mexican Courts, Queen Mary Human Rights Law Review", Volume 4, p. 24.

${ }^{37}$ Inter-American Court of Human Rights, Case of Rosendo Radilla-Pacheco v. Mexico, Judgment of November 23, 2009.

${ }^{38}$ Supra note 37,p. 16. On the subject of more favourable interpretation, see: Negishi, Y. 2017. The Pro Homine Principle's Role in Regulating the Relationship between Conventionality Control and Constitutionality Control, European Journal of International Law, Volume 28, Number 2, p. 472.
} 
Supreme Court of Costa Rica took a similar position, pointing out that priority should be given to instruments of international protection of human rights if they provide better protection than the provisions of domestic law ${ }^{39}$. However, it should be pointed out that axiological universals do not have to obscure the axiology of the Constitution, because the primacy of human dignity, from which we can derive the analyzed principle, is the "core" of international human rights law, as well as the basis of most constitutional legal orders in the world ${ }^{40}$.

\section{PrisM OF THE PRO HOMINE PRINCIPLE}

At the international stage, where there is no central legislator, the pro homine principle remains a repository of guidelines that are invaluable in the process of lawmaking, the shaping of practices of enactment of international law. The pro homine principle helps maintain objectivity in the legislative process. There exist values which comprise the "collective conscience". The Preamble of the Convention for the Pacific Settlement of International Disputes ${ }^{41}$ demonstrates that the security of states and the welfare of nations is dependent on whether the principles of justice and the principles of law that establish them are 'sanctified' through treaties. Article 1(2) of the Protocol Additional (I) to the Geneva Conventions of 1949 contains an evocation to "the dictates of public conscience", and the second Protocol of 1977 stresses that "in cases not covered by the law in force, the human person remains under the protection of the principles of humanity and the dictates of the public conscience" (Preamble) ${ }^{42}$. Pro homine emerges as a means of actualisation of human rights and preservation of a 'human' perspective in law. In the light of the above, one may conclude that the pro homine principle will not apply to the interpretation or justification of acts that violate the essence of human rights, lead to crimes against humanity and other conflicts that threaten human existence.

Therefore, conducting a dynamic interpretation of international treaties should not lead to a breach of the foundations of international law. It is important to continue to promote an attitude of permanent axiological refinement. This is exemplified by actions that were once perceived as inhumane or degrading treatment, but today are considered torture. In the 25th Paragraph of the application of Samuel Einhorn against France, 2001 (case no. 71555/01), examined by the European Court of Human Rights, it was stressed that deportation of a person to a country where they may be subjected to torture, inhumane

\footnotetext{
${ }^{39}$ Negishi, Y. 2017. The Pro Homine Principle's Role in Regulating the Relationship between Conventionality Control and Constitutionality Control, European Journal of International Law, Volume 28, Number 2, p. 474. ${ }^{40}$ Kowalska, S. 2019. Zasada pro homine - konceptualizacja i zastosowanie w kontekście międzynarodowej ochrony praw człowieka / Pro Homine Principle - Conceptualization and Application in the Context of International Protection of Human Rights. Poznań: Uniwersytet im. Adama Mickiewicza w Poznaniu, Zakład Graficzny UAM, p. 45.

${ }^{41}$ Convention for the Pacific Settlement of International Disputes signed in Hague on 18 October 1907.

${ }^{42}$ Protocols Additional to the Geneva Conventions of 12 August 1949, and relating to the Protection of Victims of International Armed Conflicts (Protocol I), and relating to the Protection of Victims of NonInternational Armed Conflicts (Protocol II), adopted on 8 June 1977.
} 
or degrading treatment or punishment (Article 3 of $\mathrm{ECHR}^{43}$ ) is contrary to "common heritage of political traditions, ideals, freedom and the rule of law" 44 mentioned in the Preamble of the European Convention on Human Rights. Interpretation of treaty norms, evaluated in the light of contemporary conditions, means that the standard of protection of human rights should continue to increase in refinement. The pro homine principle may constitute a "litmus test" aiding the detection of symptoms of arbitrariness in law-making and interpretation.

\section{Conclusions}

The pro homine principle is at the centre of international human rights law. The principle in question is derived from human dignity, which affects the way in which its functions are articulated. In the sense of an interpretative measure, the pro homine principle navigates towards a standard that provides better protection for the individual. Whereas in the sense of a principle that supports conflict resolution, it helps to find a point of contact and to select the standards which will procedurally safeguard the status of the individual in the most effective way. This means that when analysing legal norms of different hierarchical positions, the objective of the pro homine principle should be taken as a guiding light. In these circumstances, the pro homine principle may alleviate the regime resulting from the hierarchy of standards in order to reach a solution for which the individual's well-being is a priority. The article argues that the pro homine principle gives permanence to international legal obligations in the scope of protection of human rights. Values that are reflected in the pro homine principle make up the essence of human rights and their legal and axiological legitimacy.

The axiology of the pro homine principle ought to find application in the "dialogue of sources" with the aim of selection of an optimal norm or to resolve a conflict by means of its ability to act as a touchstone of the welfare of the individual. Employment of the pro homine principle in the process of interpretation may help prevent polysemous terms which could otherwise lead to the blurring of the subject and object scope of a human being. This aspect gains particular significance when the process of legislation or interpretation of the law encounters a problem of formal, procedural or inter-institutional nature or involves indeterminate phrases. The purpose of the pro homine principle is to invoke or elevate values in situations where the status of the individual is under threat. The principle's role of motivating towards respect for human rights may be conducive to shared initiatives uniting countries and international organisation. Application of the pro homine principle at the level of substantive law and procedural regulations may help remedy situations where the protection of the law is illusory and aid in neutralising merely declarative prescriptions in favour of genuine protection of the rights of the individual.

\footnotetext{
${ }^{43}$ Convention for the Protection of Human Rights and Fundamental Freedoms (European Convention on Human Rights) was opened for signature in Rome on 4 November 1950, entered into force on 8 September 1953.

${ }^{44}$ European Court of Human Rights, Application Samuel Einhorn v. France, 2001, No. 71555/01, § 25. See also application: Ilie Ilaşcu, Alexandru Leşco, Andrei Ivanţoc, Tudor Petrov-Popa v. Moldova and Russia, 2004, No. 48787/99, § 317.
} 


\section{REFERENCES}

AMAYA VILLARREAL, Á.F. (2005). El principio pro homine: interpretación extensiva vs. el consentimiento del Estado. International Law. Revista Colombiana de Derecho Internacional, 3 (5), 351.

AMERICAN DECLARATION OF THE RIGHTS AND DUTIES OF MAN adopted by the Ninth International Conference of American States, Bogotá, Colombia, 2 May 1948.

AMERICAN CONVENTION ON HUMAN RIGHTS signed in San José, Costa Rica on 22 November 1969.

BENHABIB, S. (2009). Claiming Rights across Borders: International Human Rights and Democratic Sovereignty. American Political Science Review, 103 (4), 692. https:// doi.org/10.1017/S0003055409990244

BENHABIB, S. (2009). Cosmopolitanism and Democracy: Affinities and Tensions. The Hedgehog Review. Critical Reflections on Contemporary Culture, 11 (3), 31.

BERBERA, H.R. (2017). Pro Personae Principle and its Application by Mexican Courts. Queen Mary Human Rights Review, 6, 24.

CHARTER OF THE UNITED NATIONS (1945). 26 of June, San Francisco.

CONCURRING OPINION OF JUDGE A.A. Cançado Trindade. In the connection with the Inter-American Court of Human Rights, Advisory Opinion OC-18/03 of September 17, 2003. Requested by the United Mexican States, Juridical Condition and Rights of Undocumented Migrants.

CONSTITUTION OF MEXICO (1917). 5 of February.

CONSTITUTION OF JAPAN (1946). 3 of November, came into effect on May 3, 1947.

CONVENTION FOR THE PROTECTION OF HUMAN RIGHTS AND FUNDAMENTAL FREEDOMS (European Convention on Human Rights) (1950). 4 of November, entered into force on 8 September 1953, Rome.

CONVENTION FOR THE PACIFIC SETTLEMENT OF INTERNATIONAL DISPUTES (1907), 18 of October.

DE OLIVEIRA MAZZUOLI, V., RIBEIRO, D. (2015). The Japanese Legal System and the Pro Homine Principle in Human Rights Treaties, Anuario Mexicano de Derecho Internacional, 15 (1), 268-269. https://doi.org/10.1016/j.amdi.2014.09.004

EUROPEAN COURT OF HUMAN RIGHTS (2001). Application Samuel Einhorn v. France, No. 71555/01.

EUROPEAN COURT OF HUMAN RIGHTS (2004). Application Ilie Ilaşcu, Alexandru Leşco, Andrei Ivanţoc, Tudor Petrov-Popa v. Moldova and Russia, No. 48787/99.

FLETCHER, W.A. (2010). International Human Rights and the Role of the United States, Northwestern University Law Review, 104 (1), 297. 
HELFER, L.R., WUERTH, I.B. (2016). Customary International Law: An Instrument Choice Perspective. Michigan Journal of International Law, 37, 569, 575-576.

INTER-AMERICAN COURT OF HUMAN RIGHTS. Case of Rosendo Radilla-Pacheco v. Mexico, Judgment of November 23, 2009.

INTERNATIONAL COURT OF JUSTICE. Reservations to the Convention on the Prevention and Punishment of the Crime of Genocide. Advisory Opinion of 28 May 1951.

INTERNATIONAL COURT OF JUSTICE. Reports of Judgments, Advisory Opinions and Orders, Case concerning the Barcelona Traction, Light and Power Company, Limited (Belgium v. Spain), Judgment of 5 February 1970.

INTER-AMERICAN COURT OF HUMAN RIGHTS. Advisory Opinion OC-5/85 of November 13, 1985, Compulsory Membership in an Association perscribed by Law for the Practice of Journalism (Arts. 13 and 29 American Convention of Human Rights). Requested by the Goverment of Costa Rica.

INTERNATIONAL COVENANT ON CIVIL AND POLITICAL RIGHTS adopted and opened for signature, ratification and accession by General Assembly Resolution 2200A (XXI) of 16 December 1966, entry into force 23 March 1976, in accordance with Article 49.

INTERNATIONAL COVENANT ON ECONOMIC, SOCIAL AND CULTURAL RIGHTS adopted and opened for signature, ratification and accession by General Assembly Resolution 2200A (XXI) of 16 December 1966, entry into force 3 January 1976, in accordance with Article 27.

ISHAY, M.R. (2004). What are Human Rights? Six Historical Controversies. Journal of Human Rights, 3 (3), 359. https://doi.org/10.1080/1475483042000224897

KADENS, E., YOUNG, E.A. (2013). How Customary is Customary International Law?. William \& Mary Law Review, 54 (3), 886.

KOWALSKA, S. (2019). Zasada pro homine - konceptualizacja $i$ zastosowanie $w$ kontekście międzynarodowej ochrony praw człowieka / Pro Homine Principle Conceptualization and Application in the Context of International Protection of Human Rights. Poznań: Uniwersytet im. Adama Mickiewicza w Poznaniu, Zakład Graficzny UAM, 38, 45.

MADAN, N. (2017). History \& Development of Human Rights in Indian. IOSR Journal of Humanities and Social Science, 22 (6), Ver. 9, 1. https://doi.org/10.9790/08372206090106

MARTINEZ, J.S. (2013). Human Rights and History. Harvard Law Review, 126 (7), 237.

MEDELlín URQUiAGA, X. (2013). Principio pro persona. Axotla: Suprema Corte de Justicia de la Nación, Oficina en México del Alto Comisionado de las Naciones Unidas para los Derechos Humanos y Comisión de Derechos Humanos del Distrito Federal, p. 17. 
NEGISHI, Y. (2017). The Pro Homine Principle's Role in Regulating the Relationship between Conventionality Control and Constitutionality Control. European Journal of International Law, 28 (2), 472, 474. https://doi.org/10.1093/ejil/chx030

NOONAN, J. (2018). Human Rights as Hinge Principles. International Critical Thought, 8 (3), 12. https://doi.org/10.1080/21598282.2018.1506261

OESTREICH, J.E. (2017). Development and Human Rights: Rhetoric and Reality in India Oxford: Oxford University Press. https://doi.org/10.1093/ acprof:oso/9780190637347.001.0001

OPINION SEPARATE OF JUDGE R.E. PIZA ESCALANTE is quoted for: Medellín Urquiaga, X. 2013. Principio pro persona, Axotla: Suprema Corte de Justicia de la Nación, Oficina en México del Alto Comisionado de las Naciones Unidas para los Derechos Humanos y Comisión de Derechos Humanos del Distrito Federal, p. 17.

PROTOCOLS ADDITIONAL to the Geneva Conventions of 12 August 1949, and relating to the Protection of Victims of International Armed Conflicts (Protocol I), and relating to the Protection of Victims of Non-International Armed Conflicts (Protocol II), adopted on 8 June 1977.

TOBIN, J. (2010). Seeking to Persuade: A Constructive to Human Rights Treaty Interpretation. Harvard Human Rights Journal, 23, 5.

UNIVERSAL DECLARATION OF HUMAN RIGHTS (1948), 10 of December, Paris.

VIENNA CONVENTION on the Law of Treaties was adopted on 22 May 1969 and opened for signature on 23 May 1969.

WOLFKE, K. (1964). Custom in Present International Law. Wrocław: Prace Wrocławskiego Towarzystwa Naukowego, 52.

Received: August $28^{\text {th }} 2020$

Accepted: December $12^{\text {th }} 2020$ 